\title{
Comparative leaf anatomy and micromorphology of Psychotria species (Rubiaceae) from the Atlantic Rainforest
}

Tarsila Maria da Silva Moraes ${ }^{1}$, Guilherme Rodrigues Rabelo ${ }^{1}$, Camilla Ribeiro Alexandrino ${ }^{1}$, Sebastião José da Silva Neto ${ }^{2}$ and Maura Da Cunha ${ }^{1,3}$

Recebido em 17/09/2010. Aceito em 2/02/2011

\section{RESUMO}

(Anatomia e micromorfologia comparada da folha de espécies de Psychotria (Rubiaceae) da Floresta Atlântica). O gênero Psychotria compreende aproximadamente 2000 espécies, a maioria arbórea distribuídas em florestas tropicais e subtropicais. Dentro de Rubiaceae, o gênero é bem conhecido pelas espécies produtoras de alcalóides bioativos e taxonomia complexa. Os caracteres anatômicos e micromorfológicos de $P$. hoffmannseggiana, $P$. carthagenensis, $P$. deflexa, P. glaziovii, P. leiocarpa, $P$. racemosa e $P$. vellosiana foram investigados e descritos. A variação interespecífica foi avaliada, a fim de contribuir para a sistemática do gêwnero. A análise dos componentes principais (PCA) e a análise de agrupamento através das médias não ponderadas de grupos pareados (UPGMA) indicaram quatro grupos baseados na presença e ausência de algumas características estudadas. Mesofilo dorsiventral, folhas hipostomáticas, estômatos paracíticos, organização do sistema vascular do pecíolo e da nervura principal em arco e presença de feixes acessórios são comuns nas espécies examinadas e são características típicas de Rubiaceae. A presença de cristais estilóides e de alcalóides é considerada característica diagnóstica destas espécies de Psychotria. Outras características usadas para a distinção das espécies o gênero são: o contorno do pecíolo, a ornamentação da cutícula e a presença de tricomas. Os resultados da análise de agrupamento (UPGMA) indicaram que há similaridade entre espécies de Psychotria (subg. Heteropsychotria) e Palicourea

Palavras-chave: anatomia foliar, análise de agrupamento, análise de componente principal, anatomia sistemática, domácia, superfície foliar

\begin{abstract}
(Comparative leaf anatomy and micromorphology of Psychotria species (Rubiaceae) from the Atlantic Rainforest). The genus Psychotria comprises approximately 2,000 species that are mostly shrubs distributed in forests of the tropics and subtropics. Within the Rubiaceae, Psychotria is well known for its species that produce bioactive alkaloids and for its taxonomic complexity. The anatomical and micromorphological characters of the leaves of $P$. hoffmannseggiana, P. carthagenensis, $P$. deflexa, P. glaziovii, P. leiocarpa, P. racemosa, and P. vellosiana were investigated and described to understand the interspecific variation of these species, which will contribute to the systematics of the genus. Principal component analysis (PCA) and unweighted pair group method analysis (UPGMA) indicated four groups based on the presence or absence of some of the characters studied. Dorsiventral mesophyll, hypostomatic leaves, paracytic stomata, organization of the vascular system of the petiole and midrib in an arc and the presence of accessory bundles are common in the species examined and are typical characteristics of the Rubiaceae. The presence of styloid crystals and alkaloids are considered diagnostic characters of Psychotria. Other characteristics used to separate species in the genus are the petiole contour, cuticle ornamentation, and presence of trichomes. The results of the UPGMA cluster analyses indicated that there is similarity between Psychotria (subg. Heteropsychotria) and Palicourea species.
\end{abstract}

Key words: leaf anatomy, cluster analysis, principal component analysis, systematic anatomy, domatia, leaf surface morphology

\footnotetext{
1 Universidade Estadual do Norte Fluminense, Centro de Biociências e Biotecnologia, Setor de Biologia Vegetal, Laboratório de Biologia Celular e Tecidual, Campos dos Goytacazes, RJ, Brazil

2 Universidade do Estado do Rio de Janeiro. Departamento de Botânica, Rio de Janeiro, RJ, Brazil

3 Author for correspondence: maurauenf@gmail.com
} 


\section{Introduction}

Most members of the Rubiaceae are easily recognized because they have opposite leaves with stipules, an inferior ovary, and lack internal phloem. Although the family is well defined, the limits of the subfamilies, tribes, and genera are under debate because of the large diversity of morphological characters that are still being studied, which is influencing the infrafamiliar classification (Andreasen \& Bremer 2000; Anderson \& Rova 1999; Piesschaert et al. 2000). Bremer (2009) observed a great interest in using various characteristics for phylogenetic studies on the Rubiaceae, such as ecological, evolutionary, and biogeography characters, as well as data from anatomical and morphological investigations. During the last two decades some new relationships have been completely unexpected when compared to the traditional classification of the family. Phylogenetic studies using molecular biology have proposed the division of the family into three subfamilies (Rubioideae, Cinchonoideae and Ixoroideae) and the position and definition of the tribes has also been altered (Bremer 2009; Bremer \& Eriksson 2009).

Psychotria is the largest genus in the tribe Psychotrieae (Rubiaceae) and comprises approximately 2,000 species (Davis et al. 2001). Psychotria is a tropical and subtropical genus of shrubs, treelets, and herbs (Taylor 1996). Species of the genus occur in the forest understory, in shady areas, and prefer relatively wet soil (Both 2005). The species of Psychotria that occur in the state of Rio de Janeiro, Brazil, are very important to the physiognomy of Atlantic Forest remnants in this region (Programa Mata Atlântica 2002). This genus is well known for its species that produce bioactive alkaloids and for its taxonomic complexity.

The complex taxonomy of Psychotria is not due only to the large number of species in the genus and tribe Psychotrieae, but also to the lack of morphological characters available to define groups. Systematic investigations of Psychotria and the Psychotrieae have shown that Psychotria s.l. is paraphyletic (Nepokroeff et al. 1999, Bremer 2009) or polyphyletic (Andersson \& Rova 1999) with respect to all other genera of the tribe. Based on a molecular analysis, Robbrecht \& Manen (2006) proposed to split the Psychotrieae into two tribes. However, according to Eriksson \& Bremer (2009), the analysis does not support this division and the tribe should be maintained. According to Steyermark (1972), species of Psychotria can be placed in three subgenera based on morphology and geography: Psychotria (pantropical), Tetramerae (some species in Africa and Madagascar) and Heteropsychotria (neotropical). According to Andersson (2002), the neotropical species presently belong to the following two groups: (1) species referred by Steyermark to Psychotria subgen. Psychotria; (2) most of the species referred by Steyermark to Psychotria subgen. Heteropsychotria, which forms a strongly supported, exclusively neotropical clade together with species presently recognized as belonging to the genus Palicourea. These studies indicated that the species of Psychotria subgenus Heteropsychotria are also related to the genera Geophila, Hymenocoleus and Rudgea (Nepokroeff et al. 1999).

Anatomical characters of leaves have been studied to help solve taxonomic problems. The comparative leaf anatomy and micromorphology of Simira (Moraes et al. 2009), Rondeletia (Kocsis et al. 2004), Rudgea (Mantovani \& Vieira 1993/97; Leo et al. 1997), Rustia (Vieira et al. 2001), Coussarea (Tavares \& Vieira 1994) and Bathysa (Nascimento et al. 1996) have been studied, as well as the wood anatomy of several species of Rubiaceae (Jansen et al. 1997, Dessein et al. 2001; Callado \& Silva Neto 2003). In Psychotria, leaf anatomy and micromorphology have been studied. However, these are descriptive works that do not address taxonomic issues, although this type of information is taxonomically valuable (Da Cunha \& Vieira 1993/97; Gomes et al. 1995; Vieira \& Gomes 1995).

Phenectic analysis (cluster and principal components) has been employed as a tool to better understand the patterns of morphological variation, showing relationships among taxa (see Faria et al. 2010). In the Rubiaceae, there have been studies that have tried to understand and quantify the morphological variation of complex taxa (see Jansen et al. 1997; Dessein et al. 2001), which are important because they attempted to establish which anatomical characters are diagnostically valuable and which characters can vary according to environmental influences.

The goal of the present work was to describe the anatomy and micromorphology of the leaves of seven species of Psychotria, and to understand the interspecific variation among these species, which will contribute to understanding the systematics of the genus.

\section{Materials and methods}

\section{Plants}

Completely expanded leaves were collected from individuals of Psychotria hoffmannseggiana (Willd. ex Schult) Müll.Arg., P. carthagenensis Jacq., P. deflexa DC., P. glaziovii Müll. Arg., P. leiocarpa Cham. \& Schltdl., $P$. racemosa Rich., and $P$. vellosiana Benth, from the Poço das Antas Biological Reserve. This reserve is located in the municipality of Silva Jardim $\left(22^{\circ} 30^{\prime}\right.$ and $22^{\circ} 33^{\prime} \mathrm{S} ; 42^{\circ} 15^{\prime}$ and $\left.42^{\circ} 19^{\prime} \mathrm{W}\right)$, in the state of Rio de Janeiro. Collections were made under a permit issued by IBAMA. Voucher specimens were deposited in the Herbarium of the Centro de Biociências \& Biotecnologia da Universidade Estadual do Norte Fluminense (UENF).

\section{Optical microscopy (OM)}

Samples of the leaf blades, midribs and petioles were fixed in a solution of $2.5 \%$ glutaraldehyde and $4.0 \%$ 
formaldehyde in a cacodylate buffer at $7.2 \mathrm{pH}$ (Klein et al. 2004), for two hours. Following this, the samples were washed three times with buffer for 30 minutes and then fixed for two hours at room temperature with $1.0 \%$ osmium tetroxide in a cacodylate buffer at $7.2 \mathrm{pH}$. The fixed samples were then dehydrated using an alcohol series and then embedded in glycol methacrylate resin (Leica Historesin). Thin sections $(4.0 \mathrm{~mm})$ and freehand cross sections were then made and stained with $0.05 \%$ toluidine blue (O'Brien et al. 1965). The slides were sealed with Entelan ${ }^{\circ}$ and observed using an Axioplan ZEISS optical microscope. The epidermis was detached from the leaf using a $1: 1$ solution of $10 \%$ nitric acid and $10 \%$ chromium oxide (Jensen 1962), and stained with 10\% safranin. Images were made using a Canon PowerShot A640 that was attached to the microscope.

\section{Histochemistry}

Freehand cross sections were made of fresh material and exposed to Dragendorff's reagent to test for evidence of alkaloids (Costa 1982), 10\% ferric chloride for evidence of phenolic compounds (Johansen 1940), and Sudan IV for lipids (Johansen 1940). The chemical composition of the crystals, which was calcium oxalate, was confirmed because they were insoluble in acetic acid and soluble in chloridric acid (Mclean \& Cook 1958). Images were taken using a Canon PowerShot A640 that was attached to an Axioplan microscope.

\section{Scanning electron microscopy (SEM)}

Samples of the leaves and petioles were fixed, post-fixed and dehydrated, as done for the optical microscopy study. The samples were then critical point dried, coated with $20 \mathrm{~nm}$ of gold, and observed using a ZEISS DSEM 962 scanning electron microscope.

\section{Statistical analyses}

The statistical analyses were performed using Statistica 7.0 (StatSoft 1993) and PAST (Hammer et al. 2001; version 2,01). The presence or absence of 52 morphological and anatomical characters was evaluated for the seven Psychotria species, two related species of Palicourea (Alexandrino et al. 2009) and one distantly related species, Simira pikia (K. Schum.) (Moraes et al. 2009), as the out group. Thirty-seven of these characters were selected for the principal component analysis (PCA) and unweighted pair group method analysis (UPGMA) (Table 1). The analyses that defined the groups were performed using a matrix of binary data to form similarity phenograms among the species using the UPGMA (Sokal 1986). The cophenetic correlation coefficient $(r)$ was also calculated. Principal component analysis was used to order the species and the qualitative anatomical characters, using the variances (Ludwig \& Reynolds 1988).

\section{Results}

Optical and scanning electron microscopy were used to analyze the anatomical and micromorphological characters of the leaves of each species. For example, the contour of the petiole and midrib; presence or absence of domatia; the relief of the cuticle of the epidermal surface; architecture of the external periclinal wall, and the outline of the epidermal anticlinal wall; type and location of stomata and trichomes; organization of the mesophyll; presence or absence and type of idioblasts; and the type of vascular system.

The petiole, when viewed in cross section in the middle of the structure, is biconvex in P. hoffmannseggiana (Figure 1A), P. deflexa, P. leiocarpa and $P$. racemosa with lateral projections that delimit a region that is slightly concave adaxially. In P. carthagenensis (Figure 1B) and $P$. vellosiana, the contour of the petiole is plano-convex and in P. glaziovii it is circular (figure 1C). The species have a uniseriate epidermis covered by a thin cuticle. In the region that was adjacent to the epidermis, angular collenchyma was observed. The vascular system is made of a primary collateral bundle formed in the shape of an arc (Figures $1 \mathrm{~A}-\mathrm{E}$ ) and surrounded by a sheath of perivascular fibers (Figures 1D and 1E). In P. carthagenensis (Figure 1B) and P. glaziovii (Figures 1C-E) the arc has slightly curved ends in the adaxial region. Besides the primary bundle, the presence of 1-3 accessory bundles was noted in all the species studied, except $P$. glaziovii and $P$. vellosiana. The conductive elements of the xylem were in a radial series separated by cells of parenchyma.

In the leaf blade, the cross section of the midrib is plano-convex in P. carthagenensis (Figure $1 \mathrm{H}$ ) and biconvex (Figure 1I) in the remaining species. The organization of the vascular system of the midrib is the same as the petiole. The support tissue is represented by annular (Figure 1F) or angular collenchyma (Figure 1G) that is adjacent to the epidermis in both sides and to the sheath of fibers that surrounds the vascular system. In $P$. carthagenensis (Figure $1 \mathrm{H}$ ), P. glaziovii, P. leiocarpa, and $P$. racemosa it was noted that the palisade parenchyma in the adaxial region was continuous. The presence of alkaloids was detected in the parenchyma and in the epidermal cells of the midrib. Along the abaxial surface of the midrib, domatia were observed in P. hoffmannseggiana, $P$. carthagenensis, P. deflexa (Figure 1I) and P. vellosiana. The domatia of these species are projections that arise from the tissue of the midrib and form cavities or fissures, and have trichomes on the epidermis (Figure 1J).

In cross section, the epidermis is uniseriate and covered by a thin cuticle. The external periclinal walls of the epidermal cells are slightly convex, except for those of $P$. hoffmannseggiana and P. deflexa (Figure 2A) where the walls have projections that are followed by the protoplasm originating in a papillose epidermis. Only P. carthagenensis (Figures $2 \mathrm{~B}$ and $2 \mathrm{~F}$ ) had a subepidermal layer, on the 
Table 1. Data matrix used in cluster analysis and principal component analysis.

\begin{tabular}{|c|c|c|c|c|c|c|c|c|c|c|}
\hline & barbi & carth & defle & glazi & leioc & racem & vello & wedde & P. $s p$ & pikia \\
\hline \multicolumn{11}{|l|}{ Petiole Anatomy } \\
\hline 1- Biconvex contour & + & - & + & - & + & + & - & + & + & - \\
\hline 2- Circular contour & - & - & - & + & - & - & - & - & - & - \\
\hline 3- Planoconvex contour & - & + & - & - & - & - & + & - & - & - \\
\hline 4-Annular collenchyma & + & + & + & + & + & + & + & + & + & - \\
\hline 5- Raphides crystal bundle & + & + & + & + & + & + & + & + & + & - \\
\hline 6- Accessory bundles & + & + & + & - & + & + & - & + & + & - \\
\hline 7- Vascular system in arc with curved ends & - & + & + & - & + & + & + & - & - & - \\
\hline 8- Vascular system in arc without curved ends & + & - & - & + & - & - & - & + & + & - \\
\hline 9- Vascular system in continuous cylinder & - & - & - & - & - & - & - & - & - & + \\
\hline \multicolumn{11}{|l|}{ Midrib Anatomy } \\
\hline 10- Domatia & + & + & + & - & - & - & + & - & - & + \\
\hline 11- Biconvex contour & + & - & + & + & + & + & + & + & + & + \\
\hline 12- Plan-convex contour & - & + & - & - & - & - & - & - & - & - \\
\hline 13- Tector trichomes & + & + & + & - & - & - & + & + & + & + \\
\hline 14- Angular collenchyma & + & + & + & + & - & + & - & - & - & + \\
\hline 15- Annular collenchyma & - & + & + & - & + & - & + & + & + & - \\
\hline 16- Continuity of the parenchyma & - & + & - & + & + & + & - & - & - & - \\
\hline 17- Raphides crystal bundle & + & + & + & + & + & + & + & + & + & - \\
\hline 18- Prismatic crystals & + & - & - & + & + & - & - & - & - & - \\
\hline 19- Vascular system in arc with curved ends & - & + & - & + & - & - & - & + & + & - \\
\hline 20- Vascular system in arc without curved ends & + & - & + & - & + & + & + & - & - & - \\
\hline \multicolumn{11}{|l|}{ Leaf Blade Anatomy } \\
\hline 21- Papillae & + & - & + & - & - & - & - & - & - & - \\
\hline 22- Subepidermal layer & - & + & - & - & - & - & - & - & - & - \\
\hline 23- Straight adaxial anticlinal wall & - & + & + & - & + & + & + & + & - & - \\
\hline 24- Raphides crystal bundle & - & + & + & + & + & + & - & + & + & - \\
\hline 25- Prismatic crystals & - & - & - & + & + & - & - & - & - & + \\
\hline 26- Styloids crystal & + & + & + & + & + & + & + & - & - & - \\
\hline 27- Bundle sheath extension & - & - & - & - & - & - & - & - & - & + \\
\hline 28- Parallelocytic stomata & + & + & + & + & - & + & + & - & - & - \\
\hline \multicolumn{11}{|l|}{ Micromorphology } \\
\hline 29- Adaxial surface ornamented & - & - & - & + & + & - & - & - & - & + \\
\hline 30- Abaxial surface ornamented & + & - & - & - & - & - & - & - & - & + \\
\hline 31- Papillose adaxial surface & + & - & + & - & - & - & - & - & - & - \\
\hline 32- Thin film epicuticular wax (adaxial surface) & - & + & - & - & + & + & + & + & + & + \\
\hline 33- Plate epicuticular wax (adaxial surface) & - & - & + & + & - & - & - & - & - & - \\
\hline 34- Smooth layer epicuticular wax (adaxial surface) & + & - & - & - & - & - & - & - & - & - \\
\hline 35- Thin film epicuticular wax (abaxial surface) & + & + & + & - & + & + & + & + & + & + \\
\hline 36- Plate epicuticular wax (abaxial surface) & - & - & - & + & - & - & - & - & - & - \\
\hline 37- Tector trichomes & + & + & + & - & - & - & + & + & - & + \\
\hline
\end{tabular}

barbi (P. barbiflora), carth (P. carthagenensis), defle (P. deflexa), glazi (P. glaziovii), leioc (P. leiocarpa), racem (P. racemosa), vello (P. vellosiana), wedde (Palicourea weddelliana), $P$. sp (Palicourea sp), pikia (Simira pikia). Simbol: (+) presence; $(-)$ absence. 

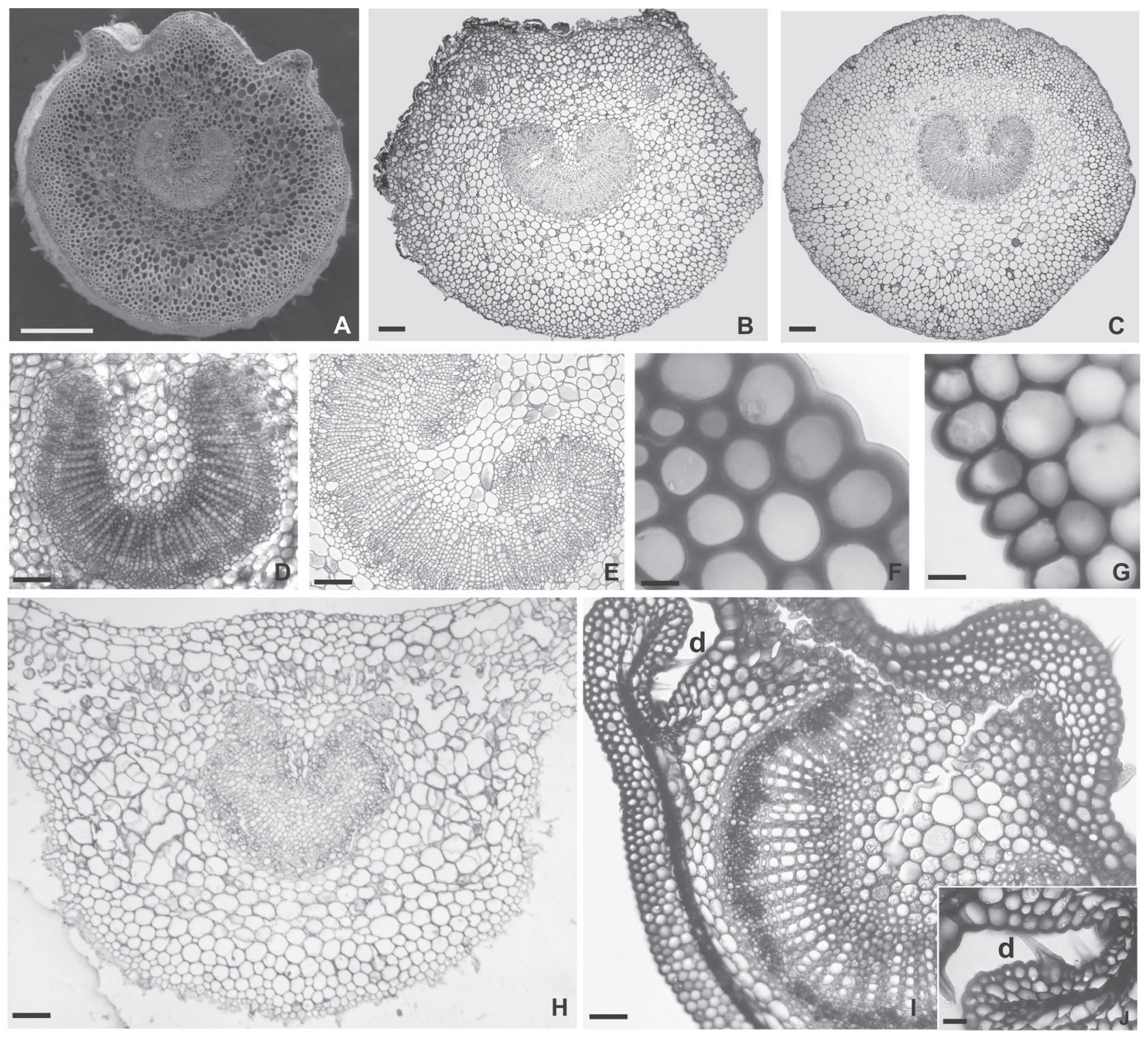

Figure 1. A-J. A-E - Cross section of petiole. A - Psychotria hoffmannseggiana. B- P. carthagenensis. C- P. glaziovii. D- P. racemosa. Note the vascular bundles in an arc. E- P. glaziovii. Note the vascular bundles in an arc with curved ends. F- Detail of the epidermis and annular collenchyma of the midrib of $P$. deflexa. G- Detail of the epidermis and angular collenchyma of the midrib of P. racemosa. H- Cross section of the midrib of $P$. carthagenensis. I- Freehand cross section of the midrib of P. deflexa J- Detail of the domatia. d - domatia. Scale bars: (A) $250 \mu \mathrm{m}$; (B, C) $20 \mu \mathrm{m}$; (D, E) $50 \mu \mathrm{m}$; (F, G, H, I) $10 \mu \mathrm{m}$; (J) $100 \mu \mathrm{m}$.

adaxial side. Viewed from the surface, the epidermal cells of the adaxial surface have straight external anticlinal walls (Figure 2C), except for P. hoffmannseggiana and P. glaziovii, and the epidermal cells of the abaxial surface have sinuous walls (Figure 2D). Stomata, paracytic (Figure 2D) and parallelocytic, are restricted to the abaxial epidermis at the same level (Figure 2E) or slightly above the level of the other epidermal cells.

The mesophyll is dorsiventral (Figures 2A, 2B and 2F), with 1-2 layers of palisade parenchyma and 3-6 layers of lacunose parenchyma. In the mesophyll, alkaloids were detected inside the cell vacuoles (Figure $2 \mathrm{~F}$ ). In all species, the vascular system has bundles arranged collaterally that are surrounded by a parenchymatous bundle sheath.
Idioblasts, comprised of raphide crystal bundles, were found in the fundamental parenchyma of the petiole (Figure 2G), the midrib, and the leaf blade; except in the leaf blades of $P$. hoffmannseggiana and $P$. deflexa. Prismatic crystals were found in the leaf blade and cortex of the midrib of P. glaziovii and P. leiocarpa and in the midrib of $P$. hoffmannseggiana. In all species, the idioblasts in the mesophyll of the leaf blade were comprised of one large solitary styloid crystal (Figure $2 \mathrm{H}$ ).

The adaxial surface of the leaf blade of Psychotria glaziovii (Figure 3A) and P. leiocarpa (Figure 3B) has cuticular grooves, whereas the cuticular ornamentations are restricted to the abaxial surface in P. hoffmannseggiana (Figure 3C). These grooves were not observed in the remaining species. 

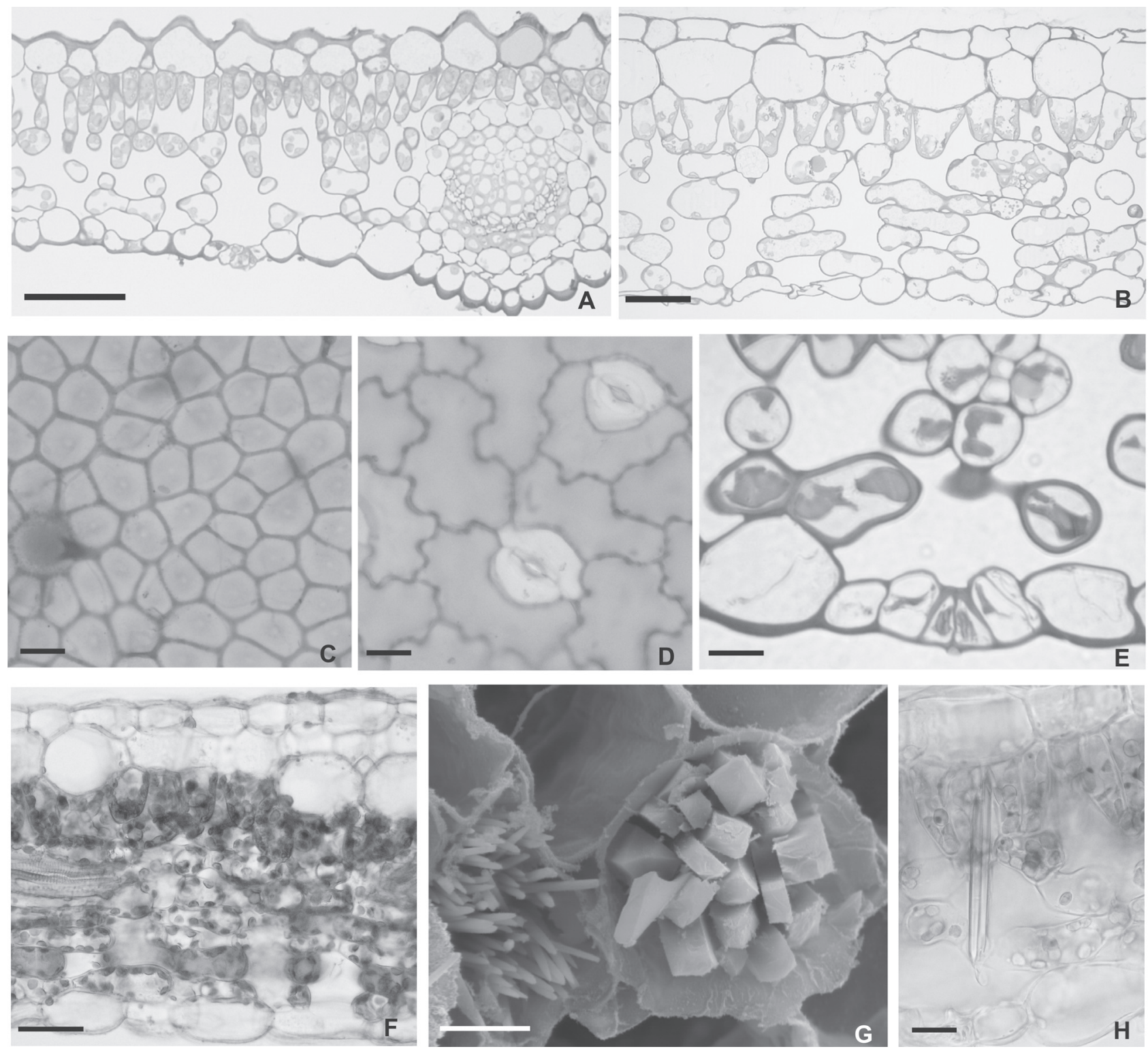

Figure 2. A-H. A- Cross section of the leaf blade of Psychotria hoffmannseggiana showing the papillose epidermis. B- Cross section of the leaf blade of $P$. carthagenensis showing the subepidermal layer. C- Surface view of the adaxial epidermis of $P$. deflexa showing the straight anticlinal walls. D- View of the surface of the adaxial epidermis of $P$. racemosa showing the wavy anticlinal walls and paracytic stomata. E- Cross section of the leaf blade of $P$. leiocarpa showing that the stomata are at the same level as the epidermal cells. F- Cross section of the leaf blade of $P$. carthagenensis (note the presence of alkaloids in the mesophyll cells). G- Idioblasts containing raphide bundles, in the parenchyma cells of the petiole of $P$. hoffmannseggiana. H- Styloid crystals in the mesophyll of $P$. deflexa. Scale bars: (A, B, F) 50 $\mathrm{mm}$; (C, D, E) $20 \mathrm{~mm}$; (G, H) $10 \mathrm{~mm}$.

The adaxial surfaces of $P$. hoffmannseggiana and P. deflexa (Figure 3D) were papillose. The surfaces of $P$. carthagenensis, P. leiocarpa (Figure 3E), P. racemosa and P. vellosiana were covered with a fine film of epicuticular wax. Plates of epicuticular wax were observed on the adaxial surface of $P$. deflexa and on both surfaces of $P$. glaziovii (Figures 3A and 3F). In P. hoffmannseggiana (Figure 3G) a smooth layer of wax could be seen on some areas of the surface. Unicellular and pluricellular tector trichomes were observed on both surfaces of $P$. hoffmannseggiana, $P$. carthagenensis, $P$. deflexa (Figure $3 \mathrm{D}$ ) and $P$ vellosiana; the remaining species were glabrous.
The UPGMA cluster analyses identified phenetic relationships among the anatomical and micromorphological characters that are illustrated in the phenogram $(\mathrm{r}=0.90$, based on the average taxonomic distance). The UPGMA cluster analyses divided the Psychotria species studied into four groups (Figure 4). The first consisted only of P. glaziovii, because of the round contour of its petiole and epicuticular wax in plates on the abaxial surface. The second group contained $P$. hoffmannseggiana and $P$. deflexa because of the presence of papillae on the adaxial surface and a smooth layer of epicuticular wax on the adaxial surface. The third group was comprised of $P$. leiocarpa and $P$. racemosa because of the 

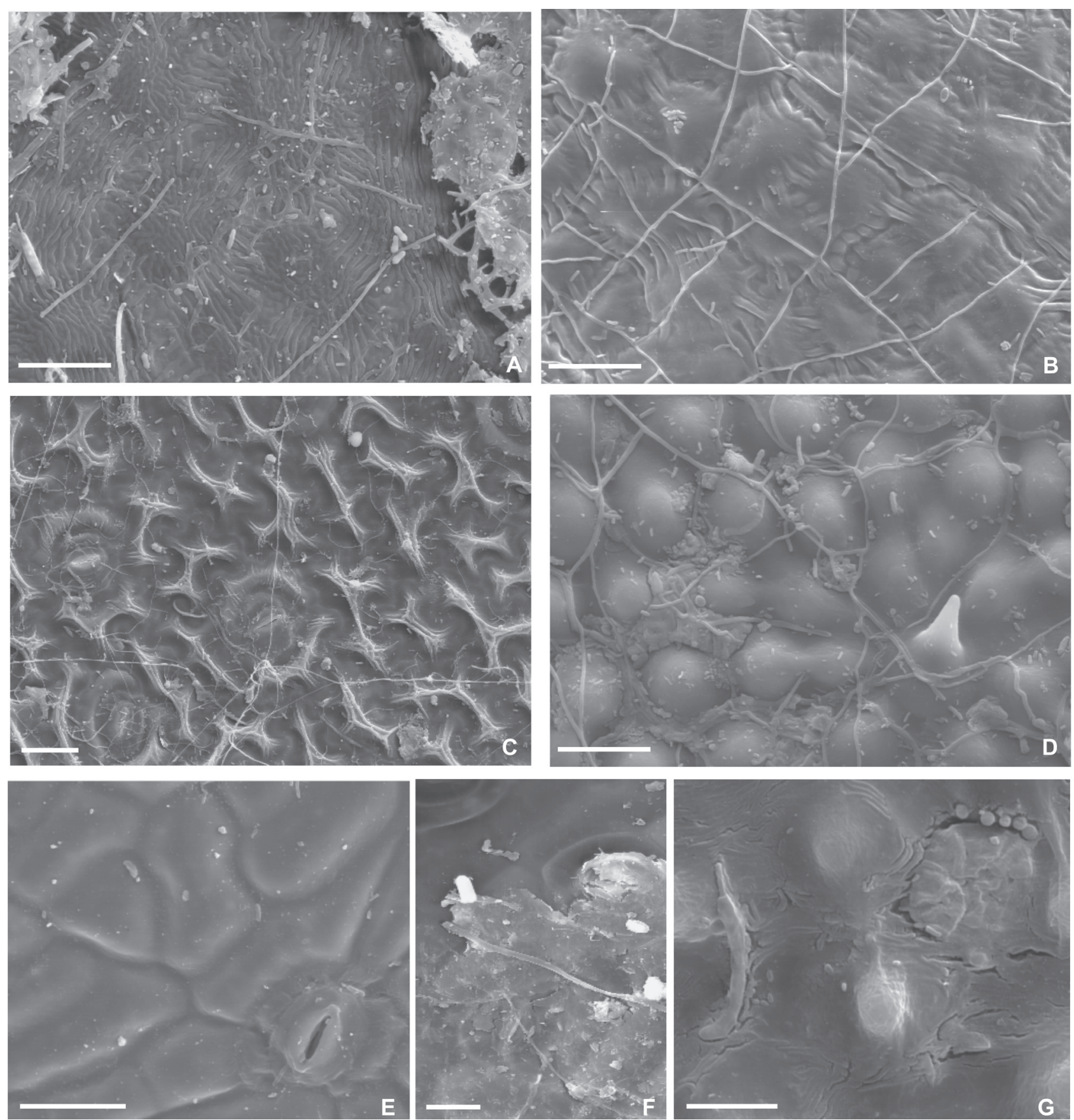

Figure 3. A-G. A- Adaxial surface ornamentation of Psychotria glaziovii. B- Adaxial surface ornamentation of P. leiocarpa. C- Abaxial surface ornamentation of P. hoffmannseggiana. D- Adaxial surface of P. deflexa showing papillose epidermis and trichome. E- Abaxial surface, without ornamentation, of P. leiocarpa with a thin film of epicuticular wax. F- Abaxial surface of P. glaziovii showing epicuticular wax in plates. G- Adaxial surface of P. glaziovii showing eipcuticular wax in a smooth layer. Scale bars: (C) $25 \mathrm{~mm}$; (D, F) $20 \mathrm{~mm}$; (A, B, E, G) $10 \mathrm{~mm}$.

absence of domatia and tector trichomes on the midrib of the leaf surface. The fourth group was comprised of P. carthagenensis and $P$. vellosiana, which have planoconvex petioles.

When the Palicourea species and Simira pikia were included, the UPGMA cluster analyses divided the taxa into six groups $(\mathrm{r}=0.81)$, but the cluster pattern of the Psychotria species remained the same (Figure 5). The cluster of Simira pikia is more distant from the other groups because of the presence of a bundle sheath extension in the leafblade and the absence of annular collenchyma and raphide crystals in the petiole. The cluster of Palicourea species showed proximity/ similarity with $P$. leiocarpa and $P$. racemosa because of the absence of domatia. The presence of styloid crystals in the leaf blade was observed only in the Psychotria species.

The PCA results indicated the formation of three groups (Figure 6). The first three components accounted for $61.28 \%$ of the total variance $(24.00 \%, 20.38 \%$ and $16.89 \%$, respectively, table 2). The first component was weighted heavily for annular 


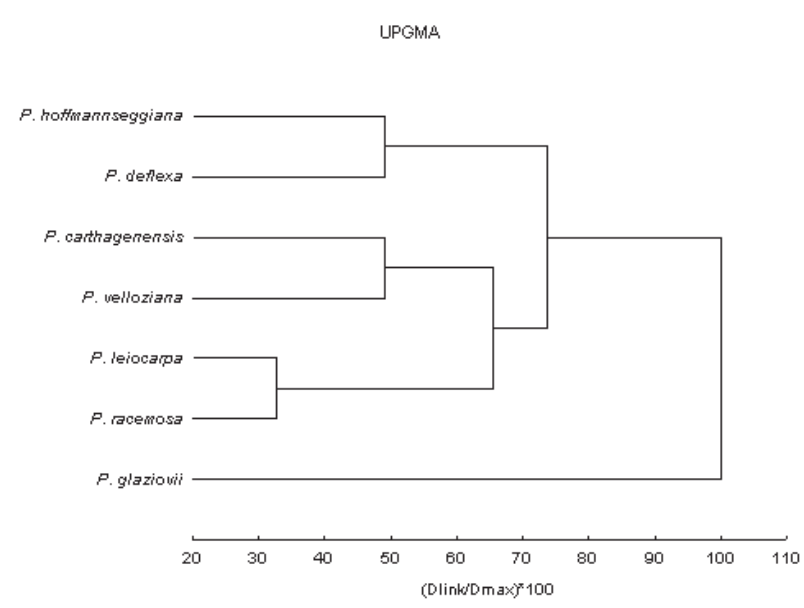

Figure 4. Phenogram showing the phenetic relationships among the anatomical and micromorphological characteristics of the Psychotria leaves based on the UPGMA cluster analyses.

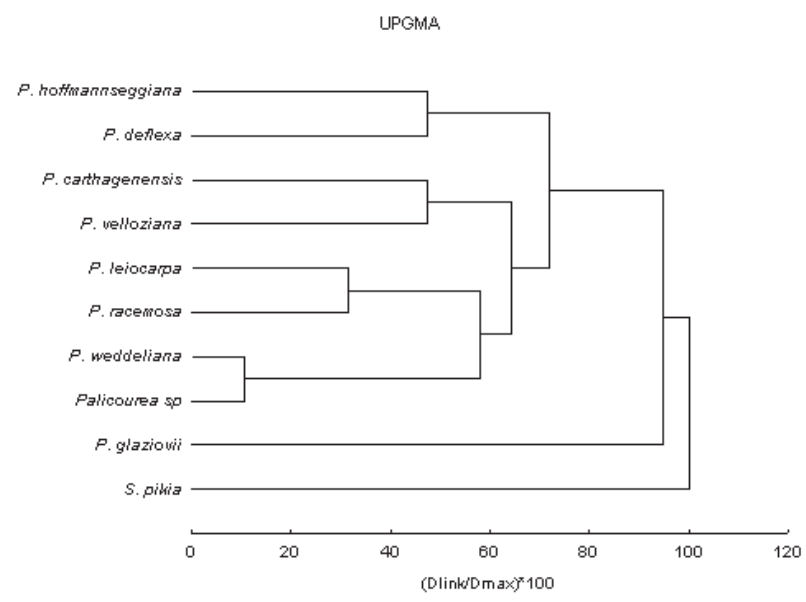

Figure 5. Phenogram showing the phenetic relationships among the anatomical and micromorphological characteristics of the Psychotria, Palicourea and Simira pikia leaves based on the UPGMA cluster analyses.

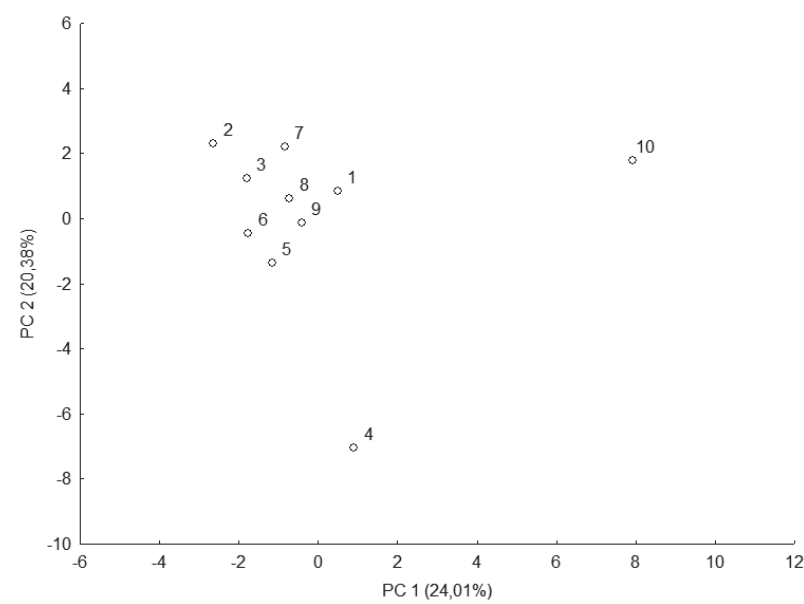

Figure 6. Principal Component Analysis. (1) Psychotria hoffmannseggiana, (2) P. carthagenensis, (3) P. deflexa, (4) P. glaziovii, (5) P. leiocarpa, (6) P. racemosa, (7) P. vellosiana, (8) Palicourea weddelliana, (9) P. sp., (10) Simira pikia. collenchyma (4; numbers in parentheses refer to characters in table 2), raphide crystal bundles in the petiole (5), a vascular system in a continuous cylinder (9), raphide crystal bundles in the midrib (17), bundle sheath extension (27), and an ornamented abaxial surface (30). The second component was weighted heavily for the circular contour of the petiole (2), tector trichomes on the midrib (13), a thin film of epicuticular wax on the abaxial surface (35), plate epicuticular wax on the abaxial surface (36) and tector trichomes on the surface (37). The third component was weighted heavily for papillae (21), a papillose adaxial surface (31), a thin film of epicuticular wax on the adaxial surface (32), and tector trichomes (37).

\section{Discussion}

Some of the anatomical characters sampled were found in all of the species studied and are common in the Rubiaceae, such as dorsiventral mesophyll, hypostomatic leaves, paracytic stomata, and collateral bundles, according to Metcalfe \& Chalk (1979). However, other characters are thought to be diagnostic for Psychotria, such as the presence of styloid crystals and alkaloids in the mesophyll.

Metcalfe \& Chalk (1950) found the petiole to be of considerable taxonomic importance, because it is not heavily influenced by environmental changes. According to Martínez-Cabrera et al. (2009), the vascular tissue arrangement is thought to be a diagnostic character that can be used at the genus level. The same authors affirmed that the distribution of the arc-shaped vascular system, in the form of a $\mathrm{V}$ with curved ends and 1-2 pairs of accessory bundles, is unique to Psychotria, and has never been described for other members of the family. The organization of the vascular system in the petiole and midrib in an arc was observed in the species studied, as well as in the leaves of other species of Psychotria previously described (Gomes et al. 1995; Quinteiro et al. 2006). However, the $\mathrm{V}$-shaped arc was not observed in our study and the vascular system of $P$. hoffmannseggiana and $P$. glaziovii did not have curved ends. The number of accessory bundles varied from 1-3 in all the species studied, except in P. glaziovii and P. vellosiana, where they were absent. The results of this study suggest that the organization of the vascular system in a V-shaped arc, curved ends of the primary vein, and 1-2 accessory bundles are not diagnostic for the genus Psychotria. This study also demonstrated that the contour of the petiole can provide information to help define $P$. carthagenensis, which has a plano-convex petiole, and P. glaziovii, which has a round petiole.

The presence of hairy pocket domatia on the abaxial surface of the leaf blade, between the midrib and secondary veins, is a common character in the Rubiaceae (Barros 1959; Robbrecht 1988). Many studies have demonstrated the relationship of these structures to small predatory and fungivorous arthropods, which defend the leaves from herbivorous arthropods and leaf pathogens (e.g., Agrawal et al. 2000; Matos et al. 2004; Rowles \& O’Dowd 2009). It 
Tarsila Maria da Silva Moraes, Guilherme Rodrigues Rabelo, Camilla Ribeiro Alexandrino, Sebastião José da Silva Neto, Maura Da Cunha

Table 2. Factor loadings and percentage of variance for the three principal components obtained from the 37 characters analysed.

\begin{tabular}{|c|c|c|c|}
\hline Characters & Component 1 & Component 2 & Component 3 \\
\hline \multicolumn{4}{|l|}{ Petiole anatomy } \\
\hline 1-Biconvex contour & -0.386700 & 0.057685 & -0.407272 \\
\hline 2-Circular contour & 0.107000 & -0.902349 & 0.014437 \\
\hline 3-Plano-convex contour & -0.307577 & 0.434193 & 0.369817 \\
\hline 4-Annular collenchyma & -0.934582 & -0.229225 & -0.157545 \\
\hline 5-Raphides crystal bundle & -0.934582 & -0.229225 & -0.157545 \\
\hline 6-Accessory bundles & -0.617244 & 0.255916 & -0.149839 \\
\hline 7-Vascular system in arc with curved ends & -0.579908 & 0.302373 & 0.155290 \\
\hline 8-Vascular system in arc without curved ends & 0.019554 & -0.448979 & -0.254969 \\
\hline 9-Vascular system in continuous cylinder & 0.934582 & 0.229225 & 0.157545 \\
\hline \multicolumn{4}{|l|}{ Midrib Anatomy } \\
\hline 10-Domatia & 0.221668 & 0.643197 & -0.337307 \\
\hline 11-Biconvex contour & 0.311377 & -0.296718 & -0.436190 \\
\hline 12-Plano-convex contour & -0.311377 & 0.296718 & 0.436190 \\
\hline 13-Tector trichomes & 0.155100 & 0.742863 & -0.133180 \\
\hline 14-Angular collenchyma & 0.225285 & -0.103904 & -0.350720 \\
\hline 15-Annular collenchyma & -0.546088 & 0.382008 & 0.358630 \\
\hline 16-Continuity of the parenchyma & -0.335761 & -0.513182 & 0.391689 \\
\hline 17-Raphides crystal bundle & -0.934582 & -0.229225 & -0.157545 \\
\hline 18-Prismatic crystal & 0.018216 & -0.635803 & -0.404591 \\
\hline 19-Vascular system in arc with curved ends & -0.206312 & -0.332447 & 0.495635 \\
\hline 20-Vascular system in arc without curved ends & -0.358606 & 0.188195 & -0.580148 \\
\hline \multicolumn{4}{|l|}{ Leaf Blade Anatomy } \\
\hline 21-Papillae & -0.116274 & 0.197884 & -0.909610 \\
\hline 22-Subepidermal layer & -0.311377 & 0.296718 & 0.436190 \\
\hline 23-Straight adaxial anticlinal wall & -0.643440 & 0.357159 & 0.269545 \\
\hline 24-Raphides crystal bundle & -0.584813 & -0.404480 & 0.376489 \\
\hline 25-Prismatic crystal & 0.592427 & -0.555409 & 0.215423 \\
\hline 26-Styloids crystal & -0.525067 & -0.191140 & -0.337989 \\
\hline 27-Bundle sheath extension & 0.934582 & 0.229225 & 0.157545 \\
\hline 28-Parallelocytic stomata & -0.407484 & -0.071460 & -0.412352 \\
\hline \multicolumn{4}{|l|}{ Micromorphology } \\
\hline 29-Adaxial surface ornamented & 0.592427 & -0.555409 & 0.215423 \\
\hline 30-Abaxial surface ornamented & 0.744032 & 0.251735 & -0.473997 \\
\hline 31-Papillose adaxial surface & -0.116274 & 0.197884 & -0.909610 \\
\hline 32-Thin film epicuticular wax (adaxial surface) & 0.031445 & 0.417999 & 0.784521 \\
\hline 33-Plate epicuticular wax (adaxial surface) & -0.079120 & -0.558694 & -0.306626 \\
\hline 34-Smooth layer epicuticular wax (adaxial surface) & 0.057461 & 0.106422 & -0.789541 \\
\hline 35-Thin film epicuticular wax (abaxial surface) & -0.107000 & 0.902349 & -0.014437 \\
\hline 36-Plate epicuticular wax (abaxial surface) & 0.107000 & -0.902349 & 0.014437 \\
\hline 37-Tector trichomes & 0.174666 & 0.705011 & -0.233209 \\
\hline Variation explained \% & 24.00541 & 20.38486 & 16.89294 \\
\hline
\end{tabular}


is believed that the domatia are formed regardless of the presence of the arthropods that live in them, and are an inherited morphological character with systematic value (Romero \& Benson 2005). The location, form, presence or absence of hairs, and the distribution of stomata near the domatia have been used as morphological characters to identify species and varieties in Coffea (Nakamura et al. 1992) and Simira and Bathysa (Silva Neto 2000; Moraes 2005; Moraes et al. 2009). In this study, the presence of domatia on the abaxial surface and along the midrib was observed in four species. These structures are made of projections of the fundamental tissue of the vein, which form cavities or fissures with trichomes, and have already been described for the genus (Da Cunha \& Vieira 1993/97; Quinteiro et al. 2006).

Epidermal characters have been used in studies on the relationship of taxa (e.g., Ayodele \& Olowokudejo 2006; Erxu et al. 2009). Some characteristics of the epidermis are influenced by environmental conditions, such as the outline of the anticlinal wall and the shape of the external periclinal wall of the epidermal cells. Barthlott (1981) believed that the sinuous appearance of the anticlinal walls of the epidermal cells was taxonomically valuable. The outline of the anticlinal wall was one of the characteristics used by Fontenelle $e t$ al. (1994) to identify species of Eugenia (Myrtaceae) and by Moraes et al. (2009) to distinguish Simira sampaioana from other species of Simira (Rubiaceae). In species of Psychotria, which grow in the understory, the outline of the anticlinal walls has been described as straight (Vieira, Gomes \& Ferraz 1992; Da Cunha \& Vieira 1993/97; Quinteiro et al. 2006). Considering that the species in our study grow in the understory, the straight outline seen in the majority of the species suggests that the expression of this characteristic is not related to light intensity and could be diagnostic.

The shape of the external periclinal walls of the epidermal cells of the species studied appear to be related to the intensity of radiation and the plants ability to capture this sunlight, because these plants are found in the understory of the forest. Epidermal cells with convex periclinal walls can be advantageous in shaded environments because they capture the light more efficiently (Smith et al. 1997). Convex periclinal walls of the epidermis have been observed in other species of Psychotria that grow in the understory (e.g., Quinteiro et al. 2006).

The presence or absence of trichomes in a species can be a diagnostic character used for identification. The trichomes of Rubiaceae can be relatively simple structures (Robbrecht, 1988). According to Metcalfe \& Chalk (1950), they may be unicellular, uniseriate, in tufts, or rarely stellate. Unicellular and multicellular tector trichomes were present in P. hoffmannseggiana, P. carthagenensis, P. deflexa and $P$. vellosiana, and were absent in the remaining species. In other studies that included species of Psychotria, the trichomes were absent, but papillae were present (Vieira et al. 1992; Gomes et al. 1995; Vieira \& Gomes 1995).
Papillae are small projections found on the external periclinal walls of epidermal cells. According to Judd et al. (2008), the occurrence of papillae is an important systematic character. Vieira et al. (1992) considered the presence of papillae on the abaxial epidermis of $P$. leiocarpa, and its absence in $P$. nuda, as a taxonomic character that could be used to identify the two species. In the species in this study, the presence of papillae on the abaxial epidermis was not observed; however, the majority of the adaxial epidermal cells of $P$. hoffmannseggiana and $P$. deflexa had papillae, which suggests that this character could be used to separate these two species from the others.

According to Robbrecht (1988), hypostomatic leaves are common in the Rubiaceae. Metcalfe \& Chalk (1950) described paracytic stomata, which are common in the family. Parallelocytic stomata have been observed in some species of Psychotria (Da Cunha \& Vieira 1993/97; Gomes et al. 1995; Vieira et al. 1995; Quinteiro et al. 2006). In our study, parallelocytic stomata were found in all species except $P$. leiocarpa.

The results of leaf surface studies have been useful to help define the genera and species of various families, such as the Podocarpaceae (Mill \& Schilling 2009), Pinaceae (Whang et al. 2004), and Myrtaceae (Fontenelle et al. 1994). According to Barthlott (1981), morphological aspects of the leaf surface, such as the presence or absence of cuticular ornamentations, can be used to separate taxa at the genus and species level. However, Dunn et al. (1965) claimed that micromorphological aspects of the leaf surface are adaptations that are influenced by habitat. Moraes et al. (2009) used this characteristic as a diagnostic feature for species of Simira (Rubiaceae). The cuticular ornamentation on the adaxial surface of $P$. leiocarpa and P. glaziovii, and on the abaxial surface of $P$. hoffmannseggiana, does not appear to occur because of exposure to sunlight, because the individuals grow in the understory of the forest. The presence, or absence, of cuticular ornamentation has already been described for Psychotria that inhabit humid shady regions (e.g., Quinteiro et al. 2006).

The appearance of wax on leaves varies from thin films to thick crusts, producing considerable micromorphological diversity that may be taxonomically interesting (Barthlott et al. 1998). Baker (1982) stated that the type of wax is genetically determined, but the quantity and distribution of the wax on the surface can be influenced by the environment. The presence of irregularly distributed granular wax has been observed on the leaf surfaces of $P$. nuda, P. leiocarpa, P. stenocalyx, and P. ternuinervis (Vieira \& Gomes 1995). The presence of wax in a smooth layer was observed in $P$. hoffmannseggiana and plates of wax were observed in $P$. deflexa and P. glaziovii, suggesting that this character can be used to separate these species.

A subepidermal layer was found only in P. carthagenensis. This character was also described in species of Bathysa (Moraes 2005) and Coussarea meridionalis (Tavares \& Vieira 
1994). According to these authors, the formation of the subepidermal layer appears to be genetically determined and is not influenced by the environment. In species of Rondeletia, the presence of a hypodermis was found (Kocsis et al. 2004). Since the ontogeny was not studied in our work, it cannot be stated whether the subepidermal layer observed in $P$. carthagenensis is a hypodermis or a multiple epidermis.

The presence of small crystals in higher plants is common and is related to physical protection, removal of oxalate from the metabolic system, storage of calcium, and regulation of light during photosynthesis in plants that grow in the shade (Franceschi \& Nakata 2005). However, the presence, distribution or type of prismatic, druse or styloid crystal can be used as a taxonomic character. Metcalfe \& Chalk (1985) cited the presence of raphide, druse, styloid, prismatic, and sand-like crystal idioblasts in species of the Rubiaceae, and raphide, druse, styloid, and prismatic crystal idioblasts have been described in species of Psychotria (Vieira et al. 1992; Da Cunha \& Vieira 1993/97; Gomes et al. 1995; Quinteiro et al. 2006). Lersten (1974) cited that the occurrence of raphide bundles is common in the subfamily Rubioideae, which contains the genus Psychotria, and that the presence of druses is frequent in South American species of Psychotria. In the species studied, the presence of druses was not observed but raphide bundles in the petiole and midrib, and styloid crystals in the leaf blade, were found in all of the species. The presence of styloid crystals in the species of Psychotria studied suggests that this might be an important diagnostic character for the genus.

According to Robbrecht (1988), the presence of alkaloids is known to occur in many genera of Rubiaceae. The presence of indole and $\beta$-carboline alkaloids have been identified in species of Psychotria (subgenus Heteropsychotria) (Lopes 1998; De Santos et al. 2001; Kerber et al. 2001; Faria 2006) and have reinforced the proposal by Solis et al. (1995) that alkaloids are important taxonomic characters that can be used to distinguish groups within a complex genus, such as Psychotria. In the species studied, the presence of alkaloids was detected in the leaf mesophyll and the midrib, which reaffirms the idea that this type of secondary metabolite is common in the genus. However, phytochemical studies are necessary to determine the chemical structures of these alkaloids.

When considering the data compiled, we conclude that the anatomy and micromorphology of the leaves of the interspecific groups and species studied could be used as diagnostic characters for the genus. The characters that contributed to the formation of the groups were a petiole with a contour that was circular or plano-convex, epicuticular wax in plates on the abaxial surface and a smooth layer of epicuticular wax on the adaxial surface, the presence of papillae on the adaxial surface, the absence/presence of domatia, the absence of tector trichomes on the midrib of the leaf surface, the presence of a bundle sheath extension in the leaf blade, and the absence of annular collenchyma and of raphide crystals in the petiole. The presence of styloid crystals in the leaf blades, observed only in the Psychotria species, suggests that this characteristic has a diagnostic value for the genus.

The results of the UPGMA cluster analyses indicated that there was similarity between Psychotria (subg. Heteropsychotria) and the Palicourea species. Results of molecular phylogenetic studies strongly support the idea that species of the entirely neotropical Psychotria subg. Heteropsychotria, together with neotropical Palicourea species, may be considered a separate genus (Nepokroeff et al. 1999) However, according to Eriksson \& Bremer, more taxa of Psychotrieae need to be investigated to support this classification. The combination of anatomical and micromorphological leaf aspects may be helpful in resolving the systematics of Psychotria, but comparative studies with the other genera (e.g., Carapichea, Chassalia, Geophila, Hymenocoleus, Palicourea Aubl.-including elements of Psychotria subg. Heteropsychotria, Chazaliella, Readea, Notopleura, Rudgea) could be helpful in resolving the systematics of the tribe.

It is worth noting that phenotypic variation due to the influence of the environment was not considered in this analysis, because the localities where the species were collected have similar microclimates.

\section{Acknowledgements}

We thank the Coordenação de Aperfeiçoamento de Pessoal de Nível Superior (CAPES), Conselho Nacional de Desenvolvimento Científico e Tecnológico (CNPq) and Fundação de Amparo à Pesquisa do Rio de Janeiro (FAPERJ) for financial support; B.F. Ribeiro and G.A. Moraes, technicians at the LBCT/CBB/UENF. This study was part of the $\mathrm{PhD}$ thesis of the first author, presented to the Programa de Pós-Graduação em Biociências e Biotecnologia/UENF.

\section{References}

Agrawal, A.A.; Karban, R. \& Colfer, R.G. 2000. How leaf domatia and induced plant resistance affect herbivores, natural enemies and plant performance. OIKOS 89: 70-80.

Alexandrino, C.R.; Miguel, E.C.; Moraes, T.M. \& Da Cunha, M. 2009. Micromorphology And Anatomy Rudgea (Salisd.) and Palicourea (Müll.Arg.) leaf blade (Rubiaceae) of the Atlantic Rainforest in the Rio de Janeiro State. Acta Microscopica 18 supp.B: B05512.

Andersson, L. \& Rova, J.H.E. 1999. The rps 16 intron and the phylogeny of the Rubioideae (Rubiaceae). Plant Systematic and Evolution 214: 161-186.

Andersson, L. 2002. Relationships and generic circumscriptions in the Psychotria complex (Rubiaceae, Psychotrieae). Systematic Geographic Plant 72: 167-202.

Andreasen, K. \& Bremer, B. 2000. Combined phylogenetic analysis in the Rubiaceae-Ixoroideae: morphology, nuclear and chloroplast DNA data. American Journal of Botany 87: 1731-1748.

Ayodele, A.E. \& Olowokudejo, J.D. 2006. The family Polygonaceae in West Africa: Taxonomic significance of leaf epidermal characters. South African Journal of Botany 72: 442-459. 
Baker, E.A. 1982. Chemistry and morphology of plant epicuticular waxes. Pp. 139-166. In: Cutler, D.F.; Alvin, K.L. \& Price, C.E., Eds. The Plant Cuticle. London, Academic Press

Barros, M.A.A. 1959. Ocorrência das domácias na família Rubiaceae. Anais da Escola Superior de Agricultura "Luiz de Queiroz" 16: 311-337.

Barthlott, W. 1981. Epidermal and seed surface characteristics of plants: Systematic applicability and some evolutionary aspects. Nordian Journal of Botany 1(3): 345-354.

Barthlott, W.; Neinhuis, C.; Cutler, D.; Ditsch, F.; Meusel, I.; Theisen, I. \& Wilhelmi, H. 1998. Classification and terminology of plant epicuticular waxes. Botanical Journal of the Linnean Society 126: 237-260.

Both, F.L. 2005. Avaliação do perfil psicofarmacológico de psicolatina isolada de Psychotria umbellata (Rubiaceae). Doctoral Thesis, Universidade Federal do Rio Grande do Sul.

Bremer, B. \& Eriksson, T. 2009. Time tree of Rubiaceae: phylogeny and dating the family, subfamilies, and tribes. International Journal of Plant Sciences 170(6):766-793.

Bremer, B. 2009. A review of molecular phylogenetic studies of Rubiaceae. Annals Missouri Botanical Garden 96: 4-26

Callado, C.H. \& Silva Neto, S.J. 2003. Anatomia do lenho de três espécies do gênero Simira Aubl. (Rubiaceae) da Floresta Atlântica do Estado do Rio de Janeiro. Rodriguésia 54(83): 23-33.

Costa, A.F. 1982. Farmacognosia. 2 ed. Lisboa, Fundação Calouste Gulbekian. V. 3.

Da Cunha, M. \& Vieira, R.C. 1993/97. Anatomia foliar de Psychotria vellosiana Benth. (Rubiaceae). Rodriguésia 45-49: 39-50.

Davis, A.P.; Bridson, D.; Jarvis, C. \& Govaerts, R.L.. 2001. The typification and characterization of the genus Psychotria L. (Rubiaceae). Botanical Journal of the Linnean Society 135: 35-42.

De Santos, L.V.; Fett-Neto, A.G.; Kerber, V.A.; Elisabetsky, E.; Quirion, J.C. \& Henriques, A.T. 2001. Indole monoterpene alkaloids from the leaves of Psychotria suterella Müll Arg. (Rubiaceae). Biochemical Systematics and Ecology 29: 1185-1187.

Dessein, S.; Jansen, S.; Huysmans, S.; Robbrecht, E. \& Smets, E. 2001 A morphological and anatomical survey of Virectaria (African Rubiaceae), with a discussion of its taxonomic position. Botanical Journal of the Linnean Society 137: 1-29.

Dunn, D.B.; Sharma, G.K. \& Campel, C.C. 1965. Stomatal patterns of dicotyledons and monocotiledons. American Midland Naturalist 74: 185-195.

Erxu, P.; Qiufa, P.; Hongfei, L.; Jingbo, S.; Yueqiang, D.; Feilai, H. \& Hui, H. 2009. Leaf morphology and anatomy of Camellia section Camellia (Theaceae). Botanical Journal of the Linnean Society 159: 456-476.

Faria, A.P.G.; Wendt, T. \& Brown, G.K. 2010. A revision of Aechmea subgenus Macrochordion (Bromeliaceae) based on phenetic analyses of morphological variation. Botanical Journal of the Linnean Society 162: 1-27.

Faria, F.M. 2006. Psychotria myriantha Mull Arg. (Rubiaceae): caracterização dos alcalóides e avaliação das atividades antiquimiotáxica e sobre o sistema nervoso central. Doctoral Thesis, Universidade Federal do Rio Grande do Sul.

Fontenelle, G.B.; Costa, C.G. \& Machado, R.D. 1994. Foliar anatomy and micromorphology of eleven species of Eugenia L. (Myrtaceae). Botanical Journal of the Linnean Society 115: 111-133.

Franceschi, V.R. \& Nakata, P.A. 2005. Calcium oxalate in plants: Formation and fuction. Annual Review of Plant Biology 56: 41-71.

Gomes, D.M.S.; Mantovani, A. \& Vieira, RC. 1995. Anatomia foliar de Psychotria ternuinerves Müll. Arg. e Psychotria stenocalix Müll. Arg. (Rubiaceae). Arquivos de Biologia e Tecnologia 38: 15-33.

Hammer, O.; Harper, D.A.T. \& Ryan, P.D. 2001. PAST: Paleontological Statistics Software Package for Education and Data Analysis. Palaeontologia Electronica 4(1): 1-9.

Jansen, S.; Robbrecht, E.; Beeckman, H. \& Smets, E. 1997. Wood anatomy of the predominantly African representatives of the tribe Psychotrieae (Rubiaceae-Rubioideae). I.A.W.A. Journal 18: 169-196

Jensen, W.A. 1962. Botanical Histochemistry (Principles Pratice). São Franscisco, W.H. Freeman and Company.

Johansen, D.A. 1940. Plant microtechnique. New York, McGraw Hill Book.
Judd, W.S.; Campbell, C.S.; Kellog, E.A.; Stevens, P.F. \& Donoghue, M.J. 2008. Plant systematics: A phylogenetic approach. Sunderland, Sinauer Associates Inc. Publishers.

Kerber, V.A.; Gregianini, T.S.; Paranhos, J.T.; Schwambach, J.; Faria, F. Fett, J.P.; Fett-Neto, A.G.; Zuanazzi, J.A.; Quirion, J.C.; Elisabetsky, E. \& Henriques, A.T. 2001. Brachycerine, a novel monoterpene alkaloid from Psychotria brachyceras. Journal of Natural Products 64(5): 677-679.

Klein, D.S.; Gomes, V.M.; Silva Neto, S.J. \& Da Cunha, M. 2004. The structure of colleters in several species of Simira (Rubiaceae). Annals of Botany 94: 733-740.

Kocsis, M.; Darók, J. \& Borhidi, A. 2004. Comparative leaf anatomy and morphology of some neotropical Rondeletia (Rubiaceae) species. Plant Systematics and Evolution 218(1-4): 205-218.

Leo, R.R.T.; Mantovani, A. \& Vieira, R.C. 1997. Anatomia foliar de Rudgea ovalis Müll. Arg. e R. tinguana Müll. Arg. (Rubiaceae). Leandra 12: 33-44.

Lersten, N.R. 1974. Morphology and distribution of colleters and crystals in relation to the taxonomy and bacterial leaf nodules in Psychotria Rubiaceae. American Journal of Botany 61: 973-981.

Lopes, S.O. 1998. Análise química e cultivo in vitro de Psychotria leiocarpa Cham. et Schlecht. e Psychotria carthagenensis Jacq. (Rubiaceae). Master Thesis, Universidade Federal do Rio Grande do Sul.

Ludwig, J.A. \& Reynolds J.F. 1988. Statistical Ecology. A primer on methods and computing. New York, John Wiley \& Sons.

Mantovani, A. \& Vieira, R.C. 1993/97. Leaf surface of two understorey shrubs Rudgea decipiens Müll. Arg. and Rudgea macrophylla Benth. (Rubiaceae). Rodriguésia 45-49: 7-13.

Martínez-Cabrera, D.; Terrazas, T. \& Ochoterena, H. 2009. Foliar and petiole anatomy of tribe Hamelieae and other Rubiaceae. Annals of the Missouri Botanical Garden 96: 133-145.

Matos, C.H.C.; Pallini, A.; Chaves, F.F.C. \& Galbiati, C. 2004. Domácias do cafeeiro beneficiam o ácaro predador Iphiseiodes zuluagai Denmark \& Muma (Acari: Phytoseiidae)? Neotropical Entomology 33: 57-63.

McLean, R.C. \& Cook, W.R.L. 1958. Plant Science Formulae. London, Macmillan \& Company Ltd.

Metcalfe, C.R. \& Chalk, L. 1950. Anatomy of dicotyledons. vol I. Oxford, Clarendon Press.

Metcalfe, C.R. \& Chalk, L. 1979. Anatomy of dicotyledons: leaves, stem and wood in relation to taxonomy with notes on economic use. vol I, 2nd edn. Oxford, Clarendon Press.

Metcalfe, C.R. \& Chalk L. 1985. Anatomy of dicotyledons: wood structure and conclusion of the general introduction. vol II, 2nd edn. Oxford, Clarendon Press.

Mill, R.R. \& Schilling, D.M.S. 2009. Cuticle micromorphology of Saxegothaea (Podocarpaceae). Botanical Journal of the Linnean Society 159: 58-67.

Moraes, T.M.S. 2005. Aspectos anatômicos e ultraestruturais da lâmina foliar de espécies de Simira e Bathysa (Rubiaceae) da floresta Atlântica do estado do Rio de Janeiro. Master Thesis, Universidade Estadual do Norte Fluminense.

Moraes, T.M.S.; Barros, C.F.; Silva Neto, S.J.; Gomes, V.M. \& Da Cunha, M. 2009. Leaf blade anatomy and ultrastructure of six Simira species (Rubiaceae) from the Atlantic Rain Forest, Brazil. BioCell 33(3): 155-165.

Nakamura, T.; Tanicughi, T. \& Maeda, E. 1992. Leaf anatomy of Coffea arabica L. with reference to domatia. Japanese Journal of Crop Science 61(4): 642-650

Nascimento, M.V.O.; Gomes, D.M.S. \& Vieira, R.C. 1996. Anatomia foliar de Bathysa stipulata (Vell.) Presl. (Rubiaceae). Revista Unimar 18(2): 387-401.

Nepokroeff, M.; Bremer, B. \& Sytsma, K.J. 1999. Reorganization of the genus Psychotria and tribe Psychotrieae (Rubiaceae) inferred from ITS and $r b c$ L sequence data. Systematic Botany 24(1): 5-27.

O'Brien, T.P.; Feder, N. \& Mccully, M.E. 1965. Polychromatic staining of plant cell walls by toluidine blue. Protoplasma 59: 368-373

Piesschaert, F.; Andersson, L.; Jansen, S.; Dessein, S.; Robbrecht, E. \& Smets, E. 2000 Searching for the taxonomic position of the African 
genus Colletoecema (Rubiaceae): morphology and anatomy compared to an rps16-intron analysis of the Rubioideae. Canadian Journal of Botany 78: 288-304.

Programa Mata Atlântica 2002. Relatório final. Jardim Botânico do Rio de Janeiro/Ibama.

Quinteiro, M.M.C.; Teixeira, D.C.; Moraes, M.G. \& Silva, J.G. 2006. Anatomia foliar de Psychotria viridis Ruiz \& Pav. (Rubiaceae). Revista da Universidade Rural, Série Ciência da Vida-RJ 26(2): 30-41.

Robbrecht, E. \& Manen, C.F. 2006. The major evolutionary lineages of the coffee family (Rubiaceae, angiosperms). Systematics Geography Plants 76: 85-146.

Robbrecht, E. 1988. Tropical woody Rubiaceae. Characteristic features and progressions. Contributions to a new subfamilial classification. Opera Botanical Belgica I. Meise: National Botanical Garden of Belgium.

Romero, G.Q. \& Benson, W.W. 2005. Biotic interactions of mites, plants and leaf domatia. Current Opinion in Plant Biology 8: 436-440.

Rowles, A.D. \& O'Dowd, D.J. 2009. Leaf domatia and protection of a predatory mite Typhlodromus doreenae Schicha (Acari: Phytoseiidae) from drying humidity. Australian Journal of Entomology 48: 276-281.

Silva Neto, S.J. 2000. O gênero Simira Aubl. (Rubiaceae, Rondeletieae) no Brasil extra-amazônico. Master Thesis, Museu Nacional Universidade Federal do Rio de Janeiro.

Smith, W.K.; Volgemann, T.C.; Delucia, E.H.; Bell, D.T. \& Shepherd, K.A. 1997. Leaf form and photosynthesys. BioScience 47: 785-793.

Sokal, R.R. 1986. Spatial data analysis and historical processes. Pp. 29-43. In: Diday, E.; Escoufier, Y.; Lebart, L.; Pages, J.; Scherktman,
Y. \& Tomassone, R. Data Analysis and Informatics IV. Holland, Elsevier Publishers.

Solís, P.N.; Langa,t' C.; Gupta, M.P.; Kirby, G.C.; Warhurst, D.C. \& Phillipson, J.D. 1995. Bio-active compounds of Psychotria camponutans. Planta Medica 61: 62-65.

StatSoft. 1993. STATISTICA. StatSoft, Tulsa.

Steyermark, J.A. 1972. Psychotria. In: Maguire BM \& Collaborators eds. The botany of the Guayana Highland - Part IX. Memoirs of the New York Botanical Garden 23: 404-717.

Tavares, E.S. \& Vieira, R.C. 1994. Anatomia foliar de Coussarea meridionalis (Vell.) Muel. Arg. e Coussarea graciliflora Benth. \& Hook (Rubiaceae). Bradea, Boletim do Herbário Bradeanium 39: 320-330.

Taylor, C.M. 1996. Overview of the Psychotrieae (Rubiaceae) in the Neotropics. Opera Botanica Belgica 7: 261-270.

Vieira, R.C. \& Gomes, D.M.S. 1995. Superfície da lâmina foliar de Psychotria nuda (Cham. \& Schltdl.) Wawra, P. leiocarpa Cham. \& Schltdl., P. stenocalix Müll. Arg. e P. tenuinervis Müll. Arg. (Rubiaceae). Acta Botanica Brasilica 9: 263-270.

Vieira, R.C.; Delprete, P.G.; Leitão, G.G. \& Leitão, S.G. 2001. Anatomical and chemical analyses of leaf secretory cavities of Rustia formosa (Rubiaceae). American Journal of Botany 88: 2151-2156.

Vieira, R.C.; Gomes, D.M.S. \& Ferraz, C.L. 1992. Anatomia foliar de Psychotria nuda Wawra e Psychotria leiocarpa Mart. (Rubiaceae). Hoehnea 19: 185-195.

Whang, S.S.; Kim, K. \& Hill, R.S. 2004. Cuticle micromorphology of leaves of Pinus (Pinaceae) from Noth America. Botanical Journal of Linnean Society 144(3): 303-320. 